\title{
A new host record for the cleptoparasite Irenangelus lucidus (Evans, 1969) (Hymenoptera: Pompilidae)
}

\author{
Léo C. da Rocha-Filho ${ }^{ \pm}$, Solange C. Augusto \\ Instituto de Biologia - INBIO, Universidade Federal de Uberlândia - UFU, Uberlândia, MG, Brazil.

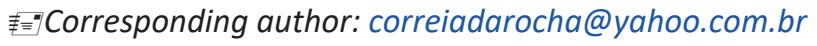

Edited by: Mabel Alvarado

Received: April 06, 2021. Accepted: May 24, 2021. Published: June 14, 2021.

\begin{abstract}
We provide a new host record for the cleptoparasitic wasp Irenangelus lucidus (Evans, 1969) (Pompilidae: Ceropalinae). A single female emerged from a brood cell of the host species Auplopus militaris (Lynch-Arribalzaga, 1873) (Pompilidae: Pepsinae) reared from a bamboo cane trap nest set at the edge of a gallery forest fragment located in Minas Gerais State, Central Brazil. This is the third host record of an Irenangelus species for the Neotropical region.
\end{abstract}

Keywords: Auplopus militaris, Ceropalinae, Gallery forest, trap-nest.

The family Pompilidae (Hymenoptera: Aculeata), commonly known as spider wasps, is a cosmopolitan group of approximately 5,000 species (Pitts et al. 2006; Waichert et al. 2015). Most of the species are ectoparasitoid, both idiobiont and koinobiont, but some species of Pepsinae, Pompilinae and the entire subfamily Ceropalinae are cleptoparasitic of other pompilid species (Wasbauer 1995; Waichert et al. 2015).

Ceropalinae is a worldwide, monophyletic group that contains only two genera: Ceropales Latreille, 1796 and Irenangelus Schulz, 1906 (Waichert et al. 2015). The genus Irenangelus is mostly distributed in the Oriental and Neotropical Regions (Shimizu \& Wahis 2007), with 12 species recorded in the New World (Kimsey \& Wasbauer 2004).

Biological data and host records of Irenangelus species are still scarce. In the Philippines, Williams (1919) recorded Tachypompilus analis (Fabricius, 1781) (Pompilinae) and Auplopus nyemitawa (Rohwer, 1919) (Pepsinae) as hosts species of I. luzonensis (Rohwer, 1919). Shimizu \& Wahis (2007) observed a female of I. hikosanus Wahis, 2007 pursuing a female of Platydialepis ryoheii (Ishikawa, 1957) transporting its prey to her nest in Japan (Pepsinae). In the Neotropical Region, Wcislo et al. (1988) reared specimens of I. eberhardi Evans, 1987 from one nest of Auplopus semialatus Dreisbach, 1963 (Pepsinae) in Costa Rica. In Brazil, Rocha-Filho et al. (2020) cited I. lucidus (Evans, 1969) as a cleptoparasite of Priochilus captivum (Fabricius, 1804) (Pompilinae).

The study was conducted in Primavera Farm (18 $50^{\prime} 30.4^{\prime \prime} \mathrm{S} /$ $48^{\circ} 23^{\prime} 46.5^{\prime \prime} \mathrm{W}$ ), approximately 1,200 hectares distant ca. $10 \mathrm{~km}$ from the city of Uberlândia, Minas Gerais State, Brazil. On February 16, 2021, we collected a nest of Auplopus militaris (Lynch-Arribalzaga, 1873) (Pepsinae) within a bamboo cane set in a wooden frame installed on the edge of a 307 ha remnant of gallery forest and Cerradão surrounded by croplands. Twenty bamboo canes from 1.4 to $2.4 \mathrm{~cm}$ diameter and $15 \mathrm{~cm}$ length were fixed horizontally in metal screens screwed to a wooden frame ( $30 \mathrm{~cm}$ height, $30 \mathrm{~cm}$ width, $20 \mathrm{~cm}$ depth) attached to a tree $1.5 \mathrm{~m}$ above ground and covered with a plastic blue roof to protect against the rain (Fig. 1A). These bamboo canes' dimensions were used to attract nesting females of giant carpenter bees, Xylocopa frontalis (Olivier, 1789) and X. grisescens Lepeletier, 1841 (Apidae) for studies on their trophic niche and nesting dynamics. Below the wooden frame, five PVC tubes of $20 \mathrm{~cm}$ length and $10 \mathrm{~cm}$ diameter containing each 24 bamboo canes ( 0.5 to $2 \mathrm{~cm}$ diameter and 9 to $25 \mathrm{~cm}$ length) were attached to attract nesting females of trap-nesting wasps and bees. The keys provided by Dreisbach (1963) and Kimsey \& Wasbauer (2004) were used to identify $A$. militaris and I. lucidus, respectively. The $A$. militaris nest was located in a bamboo cane with $21.3 \mathrm{~cm}$ length and $1.95 \mathrm{~cm}$ diameter and consisted of five brood cells attached to the bottom. The first emergence, an A. militaris female, occurred on February $21^{\text {st }}$ and a male of the same species was found dead within another brood cell. On February $22^{\text {nd }}$ and $24^{\text {th }}$ a male and a female of $A$. militaris emerged, respectively. The I. lucidus female (Fig. 1B) emerged on February $26^{\text {th }}$, two days after the last host female emergence.

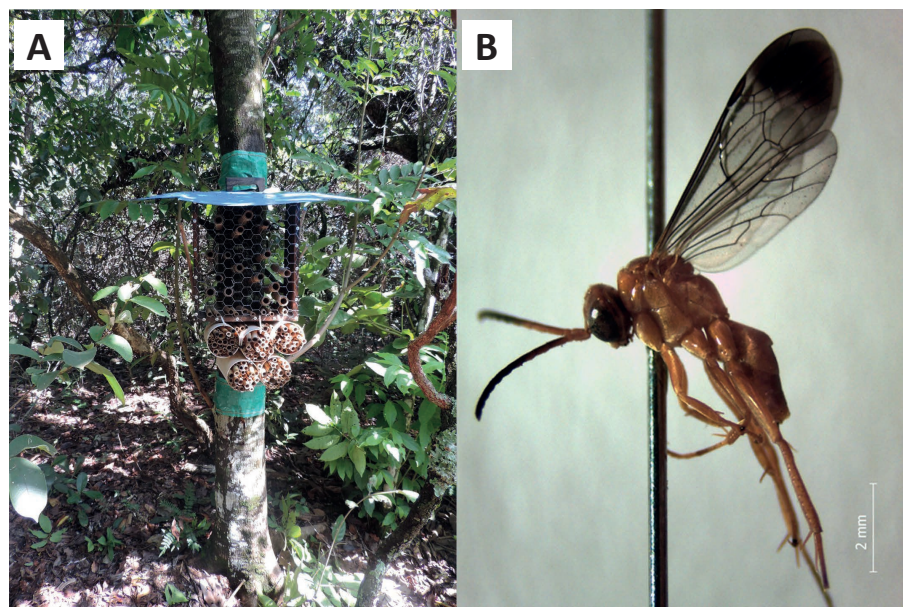

Figure 1. Wooden frame containing the bamboo canes and attached to a tree at the edge of a gallery forest at Primavera Farm (A). Lateral view of Irenangelus lucidus (B).

The data provided herein is the third host record of an Irenangelus species for the Neotropical region and the second for I. lucidus. RochaFilho et al. (2020) reared a female of this cleptoparasitic species from a nest of $P$. captivum built in a bamboo cane in an urban area with high percentage of surrounding green areas, including forests. The nest containing four brood cells was collected in February 2019 and the emergences were recorded in March, with the I. lucidus female emerging two days after the two females and one male of $P$. captivum (Rocha-Filho L. C., pers. comm.).

Seven Irenangelus species are found in Brazil (Santos 2021). However, Rocha-Filho et al. (2020) and the present study report the only host records known for this cleptoparasitic genus. Ecological studies on the communities of trap-nesting wasps and bees in different 
ecosystems are important to provide biological data and host records for some rare species such as I. lucidus.

\section{Acknowledgements}

We would like to thank 'Coordenação de Aperfeiçoamento de Pessoal de Nível Superior' (CAPES) for providing a scholarship to the first author, to 'Conselho Nacional de Desenvolvimento Científico e Tecnológico' (CNPq) for providing a research fellowship to SC Augusto and by the financial support from project 'Programa de Pesquisas Ecológicas de Longa Duração - Triângulo Mineiro e Sudeste de Goiás' (PELD/TMSG) (441225/2016-0 and 441142/2020-6). We are also grateful to 'Fundação de Amparo à Pesquisa do Estado de Minas Gerais' (FAPEMIG) (APQ 04815-17) for the financial support provided and to the owners of Primavera Farm for allowing fieldwork in the studied area.

\section{Authors' Contributions}

LCRF performed the data collection, reviewed the literature and wrote the manuscript. SCA contributed to the revision of the manuscript. All the authors approved the final version of the manuscript.

\section{References}

Dreisbach, R. R. (1963) New species of spider wasps, genus Auplopus, from the Americas South of the United States. (Hymenoptera: Psammocharidae). Proceedings of the United States National Museum, 114: 137-211. doi: 10.5479/si.00963801.114-3468.137

Kimsey, L. S.; Wasbauer, M. S. (2004) Revision of New World species of the cleptoparasitic pompilid genus Irenangelus Schulz (Hymenoptera: Pompilidae). Journal of the Kansas Entomological Society, 77: 650-668. doi: 10.2317/E-1.1

Pitts, J. P., Wasbauer, M. S.; von Dohlen C. D. (2006) Preliminary morphological analysis of relationships between the spider wasp subfamilies (Hymenoptera: Pompilidae): revisiting an old problem. Zoologica Scripta, 35: 63-84. doi: 10.1111/j.14636409.2005.00217.x

Rocha-Filho, L. C., Montagnana, P. C., Boscolo, D.; Garófalo, C. A. (2020) Green patches among a grey patchwork: the importance of preserving natural habitats to harbour cavity-nesting bees and wasps (Hymenoptera) and their natural enemies in urban areas. Biodiversity and Conservation, 29: 2487-2514. doi: 10.1007/ s10531-020-01985-9

Santos, E. F. (2021) Pompilidae. In: Catálogo Taxonômico da Fauna do Brasil. PNUD. http://fauna.jbrj.gov.br/fauna/faunadobrasil/78366. Access on: 9.iii.2021.

Shimizu, A.; Wahis, R. (2007) Systematic studies on the Pompilidae occurring in Japan: genus Irenangelus Schulz (Hymenoptera: Pompilidae: Ceropalinae). Journal of Hymenoptera Research, 16: 311-325.

Waichert, C., Rodriguez, J., Wasbauer, M. S., von Dohlen, C. D.; Pitts, J. P. (2015) Molecular phylogeny and systematics of spider wasps (Hymenoptera: Pompilidae): redefining subfamily boundaries and the origin of the family. Zoological Journal of the Linnean Society, 175: 271-287. doi: 10.1111/zoj.12272

Wasbauer, M. S. (1995) Pompilidae, In: Hanson P. E.; Gauld I. D (Eds.), The Hymenoptera of Costa Rica, pp. 522-539. Oxford: Oxford University Press.

Wcislo, W. T., West-Eberhard, M. J.; Eberhard, W. G. (1988) Natural history and behavior of a primitively social wasp, Auplopus semialatus, and its parasite, Irenangelus eberhardi (Hymenoptera: Pompilidae). Journal of Insect Behavior, 1: 247-260. doi: 10.1007/ BF01054524

Williams, F. X. (1919) Philippine wasp studies. II. Descriptions of new species and life history studies. Bulletin of the Experiment Station, Hawaii Sugar Planters' Association (Entomology), 14: 19-186. 